\title{
What matters for organisational change? Evidence from DEPZ, Bangladesh
}

\author{
Author: \\ Md. Zohurul Islam¹ \\ Affiliation: \\ ${ }^{1}$ Assistant Professor, Institute \\ of Governance Studies, \\ BRAC University \\ Correspondence to: \\ Md. Zohurul Islam \\ Email: \\ zohur68@gmail.com \\ Postal address: \\ BPATC, Savar, Dhaka-1343, \\ Bangladesh \\ Dates: \\ Received: 20 Apr. 2012 \\ Accepted: 03 May 2013 \\ Published: 02 Aug. 2013 \\ How to cite this article: \\ Islam, M.Z. (2013). What \\ matters for organisational \\ change? Evidence from \\ DEPZ, Bangladesh. SA \\ Journal of Human Resource \\ Management/SA Tydskrif vir \\ Menslikehulpbronbestuur \\ 11(1), Art. \#476, 13 pages. \\ http://dx.doi.org/10.4102/ \\ sajhrm.v11i1.476

\section{Copyright:} \\ (C) 2013. The Authors. \\ Licensee: AOSIS \\ OpenJournals. This work \\ is licensed under the \\ Creative Commons \\ Attribution License.
}

Read online:
Orientation: The role of leadership and human resources (HRM) at the managerial level in the economic zones to implement organisational change have been well described in developing countries although they are often not well documented.

Research purpose: The purpose of this article is to investigate the relationship between leadership, organisational behaviour and HRM in Dhaka export processing zone (DEPZ) enterprises.

Motivation for the study: This study has given a direction for implementing organisational change in DEPZ organisations, where leadership, organisational behaviour and HRM have significant effects on organisational change.

Research design, approach and method: The author completed a survey using a structured questionnaire on 53 enterprises in the DEPZ. The sample size was 216. The author tested the research hypotheses by using statistical tools like step-wise multiple regression analysis. The author also used Pearson correlations, a $t$-test, an ANOVA and a radar diagram in this study.

Main findings: The results provide evidence that leadership behaviour, organisational behaviour factors and HRM practices have direct relationships with organisational change. In short, it requires high level of leadership ability, employee motivation and commitment, recruitment, performance appraisal and reward to bring about effective organisational change.

Practical/managerial implications: The results show that organisational learning, transformational and transactional leadership, compensation and unionisation practices reinforce organisational change at DEPZ enterprises.

Contribution/value-add: The results of this study show that organisational change requires integration with leadership ability, organisational behaviour and HRM practices, which are useful for developing companies, industries and the national economy.

\section{Introduction}

\section{Background to the study}

Customer and consumer demands and preferences have changed rapidly. This has made businesses more competitive in the global market (Abrahamson, 2004; Rodrik, 1997).

The Dhaka export-processing zone (DEPZ) is one of the largest economic zones in terms of its export allotment, employment generation and volume of investment, especially foreign direct investment. To meet customer demands and to compete globally, the DEPZ needs to exploit its human and material resources. The DEPZ has an influence with its foreign direct investment and employment generation. The role of human resources management (HRM) is very important for linking employees' capabilities with DEPZ performance because it is a requirement of good business.

Consistent with human resources (HR) policy, the Bangladesh export processing zone authority (BEPZA) has produced Manual Instructions I and II for regulating EPZ enterprises. Nevertheless, there are some irregular activities occurring in enterprises and within as well as outside of the EPZ. As a result, they have had negative effects on investors' confidence. Workers are dissatisfied. Layoffs occur in organisations and productivity as well as performance are low (Eusuf, Faraque \& Rahman, 2007).

Businesses in the DEPZ, with its different enterprises and different countries of origin, are facing ongoing internal and external forces for change. In the DEPZ, there are both local and expatriate enterprises with local and expatriate personnel at the operational and management levels.

These enterprises interpret the circumstances according to their own frames of reference that their own perceptions and senses direct (Harigopal, 2001; OECD, 2002). Where leadership abilities 
and organisational behaviours (like organisational culture, organisational learning, motivation, values and rituals) have direct effects on organisational performance (Davis, 1984; Keller, 2007), employee behaviour differs from one employee to another. Therefore, business leaders or managers need to understand it.

The organisational behaviours this study covers human behaviour, change, team or group, leadership, human relationship and so on. These components have direct or indirect relationships with organisational change.

Researchers have conducted a number of studies on socioeconomic issues, empowerment, export performance and gender issues, whereas issues like HRM practices, leadership abilities and organisational behaviour remained almost untouched (Aggarwal, 2005; Eusuf et al., 2007; Zohir, 2001, 2007). The studies reported that BEPZA has banned trade unionisation in the EPZ because it might have negative effects on its enterprises' production.

However, the reports noted that trade unions have positive effects on wages and employment in manufacturing enterprises (Aggarwal, 2005; Bhattacharya, 1998; Eusuf et al., 2007; Hossain, 2002; Zohir, 2001, 2007). Bangladesh has also ratified International Labour Organisation (ILO) Convention 1948 (No. 87) and national collective bargaining 1949 (No. 98) for workers' rights. In addition, the Industrial Relations Ordinance XXII of 1969 has supported and protected employment conditions.

The BEPZA has banned trade unions in the EPZ because it is a threat from investors' points of view (Eusuf et al., 2007). However, Zohir (2007) asserted that unionisation could play a role for workers rights. Finally, the Bangladesh government has approved trade unionisation in the EPZ through a decision of Parliament (Government of Bangladesh [GOB], 2010). However, there have been very few studies to investigate the whole approach of HRM and industrial relations in manufacturing enterprises in South Asian countries, especially the DEPZ in Bangladesh.

\section{Research questions}

The main research question of this study is whether the success of organisational change depends on organisational behaviour, leadership and HRM practices at DEPZ manufacturing enterprises.

The specific research questions of this study follow:

- Do leadership abilities link with organisational change? If they do, to what extent?

- Are organisational behavioural components associated with organisational change in DEPZ manufacturing enterprises? If they are, to what extent?

- What are the effects of HRM practices on organisational change at DEPZ manufacturing enterprises?

Therefore, this study identifies the relationship between leadership abilities, organisational behaviour and HRM practices for organisational change in DEPZ and their effects. Finally, the study provides some managerial implications as key factors for fostering organisational change at DEPZ manufacturing enterprises.

The article is in six parts. The first part describes the DEPZ context. The second part presents a literature review and its hypotheses as they relate to:

- Leadership.

- Organisational behaviour (like organisational culture, organisational learning and employee motivation).

- HRM practices (like recruitment and selection, performance appraisal, unionisation and compensation practices) in the DEPZ.

The third part of this article covers the research method, procedure, sample organisations and questionnaire development. The fourth part of the article covers analysis and findings. The fifth part presents a discussion of the results.

Finally, the study covers the managerial implications, research limitations, future research suggestions and conclusions.

\section{The Dhaka export processing zone context}

The economic zone, called the export-processing zone, houses enterprises that vary in their patterns as well as their ownership by countries from across the world.

Business investors want to invest their capital where it is safe. This increasing trend toward special economic zones has created a large number of jobs. Currently 66 million people are engaged in economic zones from 130 countries that 3500 such zones all over the world cover (ILO, 2007). The ILO report highlights that, of 66 million people, about 55 million people work in more than 900 zones in Asia alone, especially in China and Bangladesh.

The main objective of establishing export-processing zones in Bangladesh was to attract foreign direct investment (FDI). Because of establishing export-processing zones, about 230000 people have found employment directly and about 400000 people receive indirect benefits. In particular, the DEPZ alone has generated employment for 75769 people through its 97 enterprises (Government of Bangladesh [GOB], 2009). In Bangladesh, there are 292 enterprises in operation and 205 are under construction.

HRM practices in the DEPZ are widely used in terms of labourmanagement relationships, wage level determinations, methods of recruitment and other non-financial issues like labour union or welfare issues. DEPZ enterprises follow BEPZA Manual Instructions I and II, 1989 (Government of Bangladesh [GOB], 1989) that deal with minimum wages, working hours, overtime benefits and others.

Researchers have reported that workers may not go to court to resolve grievances. Even lawyers may not look after export- 
processing zone issues and trade unions were prohibited from operating in export-processing zones before 2010 (Hossain, 2002; Bhattacharya, 1998; Zohir, 2007). Pressure from investors also prevented trade unions from operating inside export-processing zones.

Hossain (2002), Zohir (2007), Bhattaacharya (1998) and Murayama and Yokota (2009) have stated that, in the globalised competitive world, congenial working environments and mutual labour management are necessary to increase productivity. The present government has opened up trade unions and given them legitimate authority (Government of Bangladesh [GOB], 2010).

Shankar Gopalakrishhan (2007) conducted a study titled In the name of growth: The Politics and Economics of India's Special Economic Zones. A quotation gives the reaction from workers' points of view:

Appointment letters, pay slips, are not given. Minimum wages are not implemented. Workers are employed on contract basis. Overtime is compulsory but overtime wages are not paid. On the other hand, wages are deducted if the workers fail to meet the high production targets fixed unilaterally by the employers. Safety equipment or apparels are not provided, as that would increase production costs and reduce the speed and output. Women are made to work in night shifts without providing proper conveyance to their residences. They are not given maternity leave. On the other hand, women found to be pregnant are removed from service. Crèches are not provided. Young and unmarried women are only preferred. The use of toilets is controlled by issuing tokens. Sexual harassment is very common (p.47).

Bangladesh's export-processing zones and the DEPZ were operating similar HRM practices. As a result, there was unrest in the export-processing zones and the workers were dissatisfied (Eusuf et al., 2007; Zohir, 2007). Therefore, the export-processing zones need good HRM practices, organisational behaviours and leadership to reduce dissatisfaction, improve the conditions of workers and improve the performance of enterprises through organisational change.

\section{Literature review and hypotheses development Organisational change}

In the rapidly expanding business world, change has become a constant factor. To combat external forces, efficient and effective strategic initiatives are required to cope with change (Chew \& Choo, 2008). Ulrich (1997) stated that adapting to change in organisations needs regular environmental scanning. In particular, the identified change trends are globalisation, information technology and managerial innovation (Brown \& Harvey, 2006; Chew \& Choo, 2008).

Technological development has contributed to changing customer preferences in the competitive business world. This competitiveness has forced firms to revise their business strategies and employee work behaviours to sustain their competitive edge. Bangladesh has an open market economy and it has attracted foreign investment to improve its export growth and generate employment. The export-processing zones have proved to be a way of reaching those targets (Cao, Clarke \& Lehaney, 2000; OECD, 2002; Eusuf et al., 2007).

The causes of organisational change include external and internal factors. Some common external factors are technological innovations, political dynamics, economic changes, governmental issues and customer preferences. Some internal factors are organisational dynamics, inadequate administrative processes, individual expectations, structureand person-focus (Harigopal, 2001; Kreitner \& Kinichi, 2001; McShane \& Glinow, 2000).

Since the 1990s, organisational change, in the form of restructuring, downsizing and reengineering, has been a crucial management issue across the globe (World Bank, 1996). Therefore, organisations have to cope with changes in technology and other areas in order to maintain their competitive advantage. Firms survive and grow to their highest level of performance if they can effectively attract and retain the best human resources available (Arthur, 1994; Collins \& Smith, 2003; Delery, 1998; Martinez, Vela-Jimenez \& De-Luis-Carnicer, 2008; Youndt, Snell, Dean and Lepak, 1996). Wright, McMahan and McWilliams (2001) have argued that interaction, behaviours, employees' motivation and effective HR practices influence the performance of firms. Furthermore, a number of HR practices have direct positive influences on organisational performance. Therefore, there are relationships between HR practices and organisational performance (Arthur, 1994; Huselid, 1995; Pfeffer, 1994; Youndt et al., 1996). Pfeffer (1994) has stated that people are the most important assets organisations have for achieving their goals.

\section{Leadership}

In the 21st century, leadership is an important factor for coping with new challenges for business competitors (Kotter, 2007; OECD, 2001). Good leadership can lead followers and motivate employees to overcome resistance to change (Kotter, 1998). Enterprises also need leadership and best HRM practices for efficient and effective management to improve their performance. Furthermore, leadership plays an important role as a social influence to help organisations prepare for expanding globalisation.

Leadership has to focus on two orientations. The first is task orientation. It includes goal setting, scheduling, directing, coordinating, setting standards and supervising the performance of workers. The other dimension of leadership is relationship orientation. This deals with empathy, feelings, trust, appreciation and allowing subordinates to participate in making decisions (House, 1971, 1996; Lewis, Goodman \& Fandt, 2001).

More specifically, Bower and Seashore (1996) have found, in their empirical study using the data they obtained from 40 insurances agencies, that there are four dimensions of 
leadership. These are 'support', 'interaction' 'facilitation', 'goal emphasis and work facilitation'. These leadership dimensions influence organisational outcomes in many ways.

Leadership and management are equally important for company performance, where leadership plays an integrating role amongst various HRM components. They are leaders, followers and interaction between the groups (Bass, 1990; Dansereau, Yammarino \& Markham, 1995). Effective leadership always considers followers' perceptions, recognition and other determining factors that create high performance organisations (Chen \& Meindl, 1991; Kets de Vries, 1996).

In the global business environment, enterprises need visionary leadership if they are to adapt effectively to changes (Vera \& Crossan, 2004). Adapting to change depends on leadership behavioural patterns and leader-follower relationships. Transformational leadership behaviours can play vital roles in organisational change through followers' motivation. Castro, Perinan, and Bueno (2008) have stated that transformational leadership has a relationship with followers' work attitudes and it influences the behaviours of followers. Along with Castro et al. (2008), other researchers have reported that transformational leadership has a positive effect on followers' job satisfaction, work commitment and psychological empowerment (Jung, Berson, Avolio \& Bass, 2003).

Furthermore, organisational performance depends on the role clarity and commitment of employees. Therefore, transactional leadership is effective in ensuring that employees perform because it clarifies their roles, tasks and fulfils their social needs. Pawar (2003) has asserted that this type of leader is hardworking, fair minded and tolerant and has a sense of commitment to organisations.

However, empirical studies suggest that transformational leadership and transactional leadership are the most comprehensive leadership theories used in political as well as organisational contexts (Bass, 1985; Burns, 1978). In the organisational context, transactional leadership develops as an exchange process between leaders and subordinates. For example, employees receive rewards in exchange for performance (Eisenbach, Watson \& Pillai, 1999). Transformational leadership motivates followers to identify with leaders' visions and to sacrifice their own interests for those of their organisations (Bass, 1985). Furthermore, transformational leadership has a role in communicating how organisational changes will lead to better organisational performance and benefits for all (Kotter, 1995).

On the other hand, transactional leadership is more about setting goals, as the path-goal theory suggests (House \& Mitchell, 1974). Here employees do what their leaders tell them to do. To strengthen organisations, transactional leaders use strategy, structure and culture. Therefore, one can call it the contingent reward system, which is consistent with expectancy theory (Avolio, Bass \& Jung 1999; Gerhardt, 2004).

Therefore, the author hypothesises that:

H1: There is a relationship between transformational leadership and organisational change.

$\mathrm{H} 2$ : There is a relationship between transactional leadership and organisational change.

\section{Organisational behaviour}

Organisational behaviours create employees' values, assumptions, legends, rituals and the stories that people tell in organisations (Keller, 2007). Organisations can use values and beliefs as guides of employees' behaviours to achieve better performance (O'Toole, 2002; Rashid, Sambasiva \& Johari, 2003).

Leadership is central to organisational culture, which plays a key role as creator of the culture's underlying assumptions (Reimann \& Oedewald, 2002). These sets of behavioural components guide employees' attitudes and behaviours in organisations (Davis, 1984; Denison, 1990; Kotter \& Heskett, 1992; O'Reilly \& Chatman, 1996; Wilson, 2001). Organisational culture plays an important role in organisations because it adds customer value, introduces flexibility and change and sets employees' value (Daft, 2003).

In DEPZ enterprises, local and foreign employees worked side by side. Therefore, there was a mix of national and international cultures. There are also different races in the national culture. It is easy to understand that, to make organisations effective, there must be friendly relationships and shared goals amongst their people (Goffee \& Jones, 2006). Therefore, adapting shared knowledge and skills for coping with changing environments is necessary for organisational learning processes, which include acquiring knowledge, distributing and interpreting information and retaining personnel (Schermerhorn, Hunt \& Osborn, 2005).

Furthermore, effective communication is vital for implementing organisational change. DEPZ managers are in key catalytic positions for implementing change in their organisations. Furthermore, organisational change does not depend only on top managers. It is the total effort of all members in the organisations. Eventually, lower level workers become equally important. Individual behaviours, tasks, motivation and communication are equally important and integral parts of organisational change (Robertson, Roberts \& Porras, 1993).

Behavioural scientists have found that effective motivation has positive effects on organisational performance in manufacturing enterprises (Rao, 2005). Organisational performance depends largely upon workers' commitment and engagement. To get better productivity from them, firms need employees' abilities and their intrinsic motivation and 
commitment. Motivation and commitment are personal characteristics that help employees to work better (Karatepe \& Uludag, 2006).

Furthermore, in today's global business environment, change is a way of conducting better business where organisational culture guides and influences employees towards the change process (Lewis et al. 2001). Rashid et al. (2003) have asserted that organisational culture plays an important role in the change process and in determining the relationship between organisational change and employees' attitudes towards the change.

Organisational learning is another important factor for implementing organisational change. Schermerhorn et al. (2005) asserted that organisational learning is acquiring knowledge, distributing and interpreting information and adapting organisations successfully in the changing circumstances.

Goh and Richards (1997) identified some attributes for leadership. These are:

- Leadership commitment.

- The amount of freedom employees have to get the work done and the freedom to take risks.

- The degree to which employees have a clear idea of the visions and missions of their organisations.

- The extent to which employees know how they can help their organisations to achieve their goals.

Therefore, the author formulated the three hypotheses below.

H3: Employee motivation has a relationship with organisational change.

H4: Organisational culture has a relationship with organisational change.

H5: Organisational learning has a relationship with organisational change.

\section{Human resource management}

Wright et al. (1994) have identified some major HRM practices in their study upon which organisations can depend for their success. These are recruitment and selection, training and development, reward and compensation, and unionisation.

HRM practices and functions play a pivotal role in high levels of employees' performance, flexibility and commitment to organisational change (Francis, 2003). The Harvard model agrees with Francis (2003) that good HRM practices help to improve employee commitment, which ultimately contributes to successful change programmes. The Harvard model (Edger \& Geare, 2005) mentions five generic HRM practices that all organisations share. These are selection processes, placement processes, appraisal processes, reward processes and development processes. Therefore, good HRM practices are critical to maintaining competitive edge in order to align HRM with business goals and to stay relevant by embracing changes when and as required.
Zheng, Morrison and O'Neill (2006) examined the effect of HRM practices in 74 Chinese small and medium enterprises (SMEs) and identified four dimensions of HRM practices. These are performance-based pay, participatory decision-making, free market selection and performance evaluation. Based on the regression analyses, they found that good HRM practices make a positive contribution to organisational performance.

The study of Huselid (1995) stated that HRM practices are influential for organisational change as well as for improving productivity and company performance. One can identify HRM as acquiring personnel, HR planning, recruitment and selection, training and management development, performance appraisal, reward or compensation, employee benefits and employee satisfaction (Edger \& Geare, 2005; Nawaz, 2005).

Therefore, researchers have concentrated on examining the links between HRM and organisational performance. They have found that HRM links to organisational performance and is effective for maintaining competitive advantage (Becker \& Huselid, 1998; Bowen \& Ostroff, 2004; Harris, Cortvriend \& Hyde, 2007). Bowen and Ostroff (2004) asserted that there are two perspectives on HRM and organisational performance. One is a system approach and the other a strategic one.

Recently, the theme of HRM has shifted to a 'new style' of HRM designed to achieve high employee performance (Jean-Marie, 1996). HRM practices have direct relationships with organisational policy and company performance issues, whilst in the past it was traditional personnel management (Arthur, 1994; Bach \& Sisson, 2000; Francis, 2003; Huselid, 1995).

Given their global challenges, organisations need to acquire qualified employees through effective HRM practices, like recruitment and selection. Bohlander and Snell (2004) stated that recruitment is the process of locating potential applicants and stimulating them to apply for jobs. Noe, Hollenbeck, Gerhar and Wright (2006) state that the selection process is identifying the candidates with skills, knowledge, ability and some other characteristics that will help organisations to achieve their goals. Hossain (2002) asserted that DEPZ enterprises recruit with notice board advertisements and interview short-listed candidates.

How well employees are doing their jobs to make suitable decisions is important for HRM (Thang, 2004). Stone (2002) has asserted that, in the competitive world, organisations need to improve performance to survive. Where employee behaviours and organisational culture influence organisational performance, previous studies have suggested that performance-related rewards are conducive for ensuring high performance. Therefore, measuring employee performance is important for individual and organisational development. However, performance appraisal links to employee recruitment, selection, training and development, career planning, compensation and 
benefits as well as industrial relations. Noe et al. (2006) identified that performance appraisal is the central part of management, that is, evaluation by supervisors, review by peers, subordinates and managers.

According to Bohlander and Snell (2004), direct compensation comprises wages, salaries, incentives, bonuses and commissions. Later on, organisations can offer non-monetary benefits like flexible work time, recognition, reward for work and working environment. Therefore, compensation and reward can be powerful tools for getting the efforts organisations want from employees to reach their organisational goals (Thang, 2004). Noe et al. (2006) stated that compensation includes pay structure decisions, employees' contributions and employees' benefits.

Empirical research findings suggest that unionised firms have higher wages and productivity than non-unionised firms do (Siengthai \& Bechter, 2001). To face the challenges of globalisation and privatisation in Bangladesh, organisations need increased productivity. Hossain (2002), Eusuf et al. (2007) and Zohir (2007) have yielded results that contradict this view: that the BEPZA ban on trade unions in exportprocessing zones is the most prudent approach given that export-processing zone trade unions are irresponsible and not production-orientated.

However, the object of unionisation is job security. Once employees have secured work, unions fight to improve wages, working hours, working conditions and so on. Unions have a role in HRM activities. They include recruiting, selecting, compensating, promoting, training, collective bargaining and discharging employees (Dessler, 2003; Chen, 2007; Gooderham, Parry \& Ringdal 2008).

Therefore, the author formulated four hypotheses.

H6: Effective recruitment and selection practice relates to organisational change.

H7: Performance appraisal practice relates to organisational change.

H8: compensation or reward practice has a relationship with organisational change.

H9: There is a relationship between unionisation and organisational change.

\section{Research design}

This research followed a quantitative approach using a structured questionnaire survey. This is a study where the author measured in-depth understandings of human behaviour and organisational change, HRM practices, organisational behaviour and leadership competencies using different items and a Likert scale as a measuring tool. Therefore, to answer the formulated research questions, the author used a qualitative research method.

\section{Research approach}

In order to answer the three research questions, this study used primary data the author collected from a questionnaire survey. The author used scale variables to get primary data related to organisational change, organisational behaviours, leadership competencies and HRM practices. The author used the variables' relationship and their coefficient regression, along with a post-hoc analysis method, to answer the questions. The author also conducted a Cronbach alpha test to identify the reliability of the variables

\section{Research method \\ Research participants}

The author used 216 participants in this study. They were managers of manufacturing enterprises from 53 enterprises.

The respondents comprised $189(86.10 \%)$ males and 27 (13.90\%) females. Of these, $64.4 \%$ were managers and $35.6 \%$ were assistant managers. Most participants (98.60\%) had higher levels of education. The managers had worked in their current positions for a significant number of years (mean $=7.80, \mathrm{SD}=2.45$ ). The author found that the survey organisations were members of practicing workers' unions. Only $58.49 \%$ worked at top management level. Seniority at workers' unions was through selection $(83.02 \%)$ rather than election (16.98\%).

\section{Sample organisations}

The author drew participants for this study from three types of enterprises. Of the enterprises, $53(62.27 \%)$ were foreign investor-owned ( $A$-type) enterprises, $13.20 \%$ were from jointly owned ( $B$-type) enterprises and $24.53 \%$ were localinvestor owned ( $C$-type) enterprises in the DEPZ. There were $137(63.40 \%)$ participants from foreign investor-owned enterprises, $28(13.00 \%)$ participants were from joint venture enterprises and $51(23.60 \%)$ were from local investor-owned enterprises. The author used simple random sampling for this study.

\section{Measuring instruments}

The author used a five-point Likert (1932) response scale for this study except when gathering demographic and enterprise information. The scale ranged from ' 1 ' (strongly disagree) to ' 5 ' (strongly agree) and from ' 1 ' (not at all) to ' 5 ' (very well).

Dependent variable. The author measured organisational change using 13 items. The author measured all the items using a 5-point Likert scale. Organisational change items included organisational structure, present pay system or pay scale, team culture activities, labour-management relations, adapting new technology, new work processes, new information technology (IT) systems, employee participation and openness to change.

Independent variables. The author measured organisational behaviours (OB) with some selective components or variables 
like organisational culture, organisational learning and employee motivation. This group of variables contained 23 items. Several other researchers, like Parker and Bradely (2000), Robbins (2003), Andrew (1998), Koskosas, Charitodui and Louta (2008), Schein (1992), Tsang (1997), Senge (1990), Pedler, Burgoyne and Boydell (1991), Thomas, Sussman and Henderson (2001) have used the measured items. The author measured the items using a Likert 5-point scale (Stroh, Brett, Baumann \& Reilly, 1996). It ranged from ' 1 ' (strongly disagree) to ' 5 ' (strongly agree).

The leadership (transformational and transactional leadership) inventory contains 16 items. Of the 16 items, the author used five for transformational leadership and five for transformational leadership. The author adapted the list from other studies (Bass, 1985, 1990; Burns, 1978; Podsakoff, MacKenzie \& Bommer, 1996; Das, 2006) and measured them using a Likert 5-point scale that ranged from ' 1 ' (not at all), '2' (to some extent), '3' (average), '4' (well) and '5' (very well).

HRM. In this study, there are 20 items of core HRM practices. Many scholars, like Huseild (1995) and Datta, Guthrie and Wright (2005), developed the items. They include recruitment and selection, training and development, appraisal and compensation and employees' trade unions for collective bargaining about their welfare and development.

\section{Research procedure}

The author gathered the data of this study using field surveys he conducted during January 2008 to July 2008 using structured questionnaires. The author distributed the structured questionnaires to the 512 manager-level officers in 53 enterprises. With prior telephonic communication, the author used simple random sampling to select the enterprises.

The author collected 216 completed questionnaires from these 53 sample firms. The response rate was $42.18 \%$. This is satisfactory and statistically acceptable (Babbie, 2004). The author was directly involved in the process of collecting field data and received good cooperation from the HR managers of the sample firms in the DEPZ.

\section{Results}

The descriptive statistics in Table 1 show the means, standard deviations, the Pearson correlations and Cronbach's Alpha reliability.

The author computed Pearson correlations to determine the relationships between all the variables in DEPZ enterprises and the strengths of their relationships for organisational change. The results provide an understanding of direct relationships between employee motivation, organisational learning, organisational culture, transactional leadership, transformational leadership, recruitment and selection, performance appraisal, unionisation, compensation or reward and organisational change.

Table 1 also reports the values of Cronbach's Alpha. The author found that the values do not support all the variables,

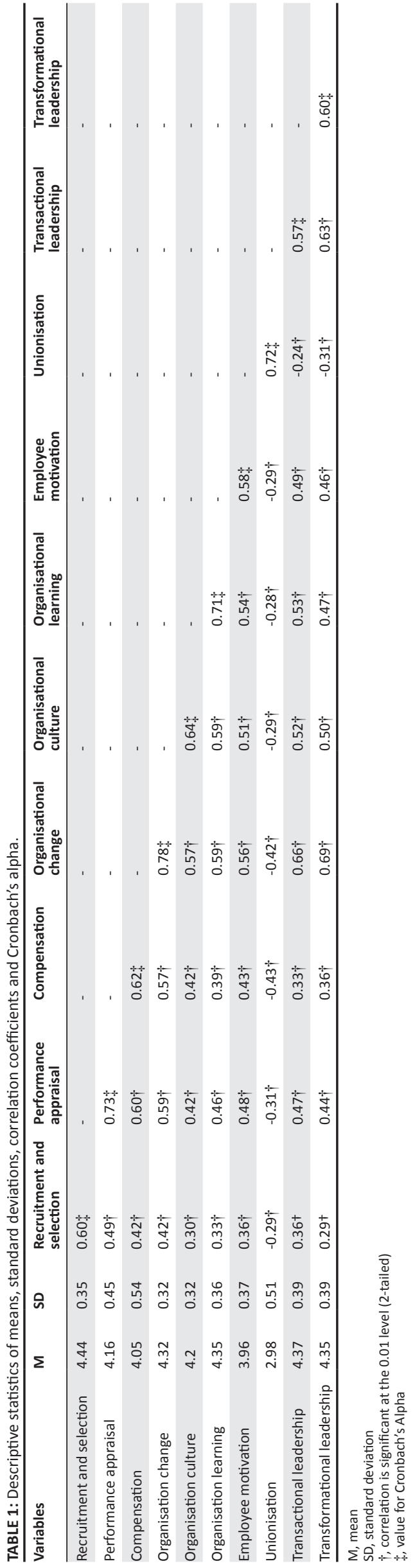


as Hair, Anderson, Tatham, Black and Babin, (2006) recommends, but all of them are above the 0.50 level, as Nunnally (1978) requires.

Table 2 gives the results of the hypotheses testing. The author ran step-wise multiple regressions to measure variables like transformational leadership, transactional leadership, unionisation, recruitment and selection, organisational learning, compensation or reward, employee motivation, organisational culture and performance appraisal for organisational change.

The regression results in model 3 reveal that there is a positive relationship between the independent and dependent variables. The correlation coefficient is 0.838 . The $R^{2}$ adjusted is 0.682 . Therefore, the model, which comprises the specified variables of employees' motivation and commitment, organisational learning, organisational culture, transformational leadership, transactional leadership, recruitment and selection, performance appraisal, compensation or reward and unionisation explains about $68.2 \%$ of the total variation in organisational change. The result is also statistically significant at the 0.05 level.

On the other hand, model 2 was significant. It comprises the hypothesised variables. The adjusted $R^{2}$ explained $69.5 \%$ of the total variance.

Of the three regression models, model 1 is not significant.

In Table 2, the regression model 3 also illustrates the coefficients for compensation or reward, organisational learning, transformational leadership and transactional leadership behavioural abilities, which are positive and have a significant relationship with organisational change.

The author found that bun ionisation has a negatively significant relationship with organisational change in DEPZ enterprises. Specifically, organisational learning has a positive and significant relationship and explained 13\% of total variance in organisational change.

Transformational leadership has a highly positive significant relationship with organisational change. This explained $29.8 \%$ of the total variance. Transactional leadership also has a positive and significant relationship with organisational change. This explained $18 \%$ of the total variance.

Compensation or reward practices have positive and significant effects on organisational change. This explained $18.9 \%$ of the total variance.

Furthermore, Table 2 shows that the recruitment and selection, performance appraisal, organisational culture and employee motivation and commitment variables have positive relationships with organisational change, although the relationships were not significant. The significance level was 0.05 .

To determine the group variable effect on organisational change, the author entered group variables like gender and position (manager and assistant manager) and ran compared means by using SPSS statistical software.

Table 3 reveals that there was no significant difference between groups on organisational change. Therefore, there is no mean difference between males and females or between managers and assistant managers on organisational change.

The author later ran a post hoc test on the respondents' education levels and type of enterprises on which they work to determine the comparative results and their effects on organisational change.

Therefore, the author entered the respondents' education levels (Bachelor, Master of Business Administration [MBA]

TABLE 2: Regression model of demographic and independent variables with organisational change.

\begin{tabular}{|c|c|c|c|c|c|}
\hline Independent variables & Model 1 & Model 2 & $t$-value & Model 3 & $t$-value \\
\hline Age of the respondents & 0.156 & - & - & -0.017 & -0.296 \\
\hline Gender of the respondent & -0.045 & - & - & -0.015 & -0.341 \\
\hline Education level of the respondents & -0.118 & - & - & 0.028 & 0.698 \\
\hline Service length of the respondents & 0.068 & - & - & 0.059 & 1.077 \\
\hline Positions of the respondents & 0.102 & - & - & -0.077 & -1.838 \\
\hline Recruitment and selection & - & 0.024 & 0.519 & 0.035 & 0.752 \\
\hline Compensation & - & $0.180 \%$ & 3.416 & $0.189 \S$ & 3.575 \\
\hline Unionisation & - & $-0.091 \dagger$ & -2.083 & $-0.100 \%$ & -2.250 \\
\hline Transactional leadership & - & $0.199 \S$ & 3.606 & $0.180 \ddagger$ & 3.242 \\
\hline Transformational leadership & - & $0.305 \S$ & 5.779 & $0.298 \S$ & 5.557 \\
\hline Organisational culture & - & 0.054 & 1.037 & 0.053 & 0.993 \\
\hline Organisational learning & - & $0.120 \dagger$ & 2.246 & $0.130 \ddagger$ & 2.423 \\
\hline Employee motivation & - & 0.069 & 1.353 & 0.084 & 1.646 \\
\hline$R^{2}$ & 0.035 & 0.694 & - & 0.703 & - \\
\hline Adjusted $R^{2}$ & 0.012 & 0.680 & - & 0.682 & - \\
\hline$F$-value & 1.534 & $51.798 \S$ & - & $33.929 \S$ & - \\
\hline$N$ & 216 & 216 & - & 216 & - \\
\hline
\end{tabular}


or Masters) and type of enterprises (A, B and C type) and ran comparative means.

Table 4 reveals that bachelor and Master degrees have no significant effects on organisational change. On the other hand, MBA has positive and significant effects on organisational change at DEPZ manufacturing enterprises. Therefore, respondents with business administration degrees have positive and significant effects on organisational change whilst other education degrees do not.

Table 5 reveals that the overall ANOVA is significant. Therefore, the population means are not equal. ANOVA significant test results recommend a Least Significant Difference (LSD) post hoc test. The results showed that there are significant mean differences for organisational change in DEPZ manufacturing enterprises. Again, the type of enterprises has a significant effect on organisational change in DEPZ manufacturing enterprises.

\section{Analysis of Variance with type of Dhaka export processing zone enterprises}

There were three types of enterprises in the DEPZ. These were ' $A$ ' (foreign owned enterprises), ' $B$ ' (joint venture enterprises) and ' $\mathrm{C}$ ' (locally owned enterprises). Each type has 216 observations or cases $(N=216)$.

Table 5 gives a one-way analysis of variance (ANOVA). It shows that the means differ significantly with organisational change in DEPZ enterprises.

\section{Post hoc test for type of enterprise in the Dhaka export processing zone}

The overall ANOVA is significant (see Table 5). Therefore, the population means are not equal. The ANOVA significance test results recommend a LSD post hoc test run. The results revealed that there are significant means differences for organisational change in DEPZ manufacturing enterprises. The type of enterprise (foreign owned, joint venture and locally owned enterprise) has a significant effect on organisational change in DEPZ manufacturing enterprises.

\section{Links of all independent variables with organisational change in Dhaka export processing zone enterprises}

The radar diagram (Figure 1) shows the variables' links with organisational change in DEPZ manufacturing enterprises. The graphical presentation includes overall leadership abilities, organisational behaviours and HRM practices. This radar diagram is a descriptive and graphical presentation to examine the link between independent variables and organisational change in DEPZ. This figure uses the mean value of all variables. Therefore, the shape of the diagram denotes how leadership abilities, organisational behaviours and HRM practices link or associate with organisational change and its effect on organisational change.

The figure shows that all the variables are very close to the upper limit of the radar, whilst unionisation is a little further away from the others.

\section{Discussion}

This study tries to investigate the relationships between variables like leadership abilities, organisational behaviours

TABLE 3: $t$-Test - organisational change based on gender and position.

\begin{tabular}{llllll}
\hline Grouping variable & Item & Mean & Standard error mean & $t$-value & 0.648 \\
Gender & Male & 4.3337 & 0.02309 & 0.562 & 0.518 \\
& Female & 4.2923 & 0.07002 & 0.578 \\
Position & Manager & 4.3509 & 0.02602 & 1.394 & 0.0641 \\
& Assistant Manager & 4.2867 & 0.04021 & 1.339 & 0.0641 \\
\hline
\end{tabular}

TABLE 4: Post hoc test for organisational change - education and type of enterprises.

\begin{tabular}{|c|c|c|c|c|c|}
\hline Education level (I) & Education level (J) & Mean difference (I-J) & Standard error & $d f$ & Level of significance \\
\hline \multirow[t]{2}{*}{ Bachelor } & MBA & -0.1109 & 0.19283 & 2.114 & 0.566 \\
\hline & Master's & 0.0023 & 0.18807 & & 0.990 \\
\hline \multirow[t]{2}{*}{ MBA } & Bachelor & 0.1109 & 0.19283 & 2.114 & 0.566 \\
\hline & Master's & $0.1132 \dagger$ & 0.05512 & & 0.041 \\
\hline \multirow[t]{2}{*}{ Foreign owned } & Joint venture & $0.2511 \dagger$ & 0.06328 & 15.766 & 0.000 \\
\hline & Locally owned & $-0.1514 \dagger$ & 0.05007 & 9.144 & 0.003 \\
\hline Joint venture & Foreign owned & $-0.2511 \dagger$ & 0.06328 & 4.482 & 0.000 \\
\hline
\end{tabular}

$\dagger$, The mean difference is significant at the 0.05 level.

$d f$, degrees of freedom

TABLE 5: ANOVA test for type of enterprise in the DEPZ.

\begin{tabular}{|c|c|c|c|c|c|c|}
\hline \multirow[t]{2}{*}{ Test Statistics } & \multirow[t]{2}{*}{ Between groups } & \multicolumn{3}{|c|}{ Linear term } & \multirow[t]{2}{*}{ Within groups } & \multirow[t]{2}{*}{ Total } \\
\hline & & Unweighted & Weighted & Deviation & & \\
\hline Sum of squares & 2.931 & 0.850 & 0.417 & 2.515 & 19.710 & 22.641 \\
\hline$d f$ & 2 & 1 & 1 & 1 & 212 & 214 \\
\hline Mean square & 1.466 & 0.850 & 0.417 & 2.515 & 0.093 & - \\
\hline$d f$ & 15.766 & 9.144 & 4.482 & 27.049 & - & - \\
\hline Significance level & 0.000 & 0.003 & 0.035 & 0.000 & - & - \\
\hline
\end{tabular}

$d f$, degrees of freedom 


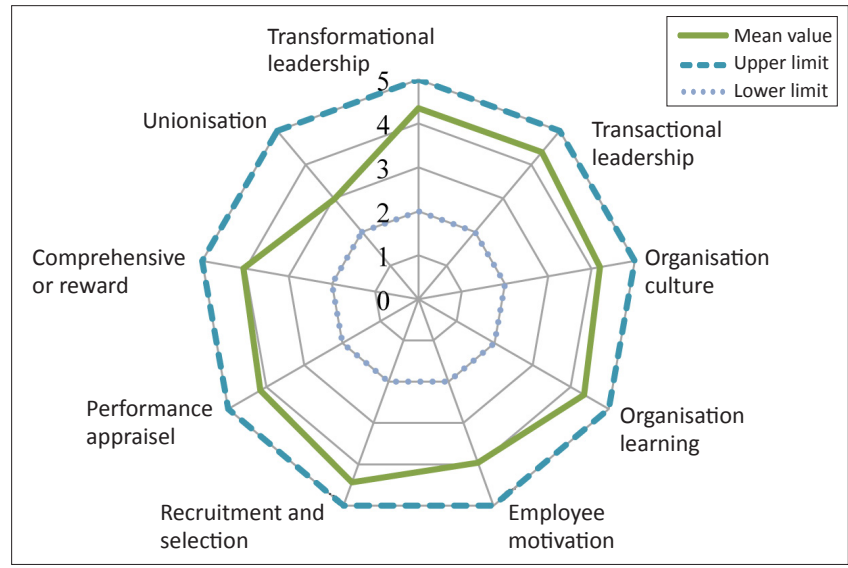

FIGURE 1: Radar diagram for independent variables.

and HRM practices with organisational change in DEPZ manufacturing enterprises at managerial level. Furthermore, this study tries to determine the relationship between the variables and their effects on organisational change.

However, based on the regression analyses, the author found that only five independent variables had a statistically significant relationship with organisational change. These are organisational learning, transformational leadership, transactional leadership, compensation or reward and unionisation.

For this study, the author measured organisational learning using items like 'acquiring and sharing knowledge', 'commitment to continuous learning' and 'team autonomy (Huber, 1991; Senge, 1990; Stata, 1989) in making decisions about behavioural change in competitive businesses'. Managers are the key drivers of organisational change and their approaches to nurturing organisational learning through shared vision, personal mastery, mental models, team and system learning (DiBella, Nevis \& Gould, 1996; Senge, 1990) are critical. Alas, Vadi and Sun (2009), Dumphy, Turner and Crawford (1997) and Gravin (1993) have treated organisational learning as outcomes.

This study result confirms the measuring items $(\alpha=0.71)$ (Nunnally, 1978) and supports the previous findings. It also confirms that organisational learning has positive and significant relationships with organisational change $(b=0.13, p<0.05)$.

According to the transformational leadership approach (Bass, 1985; Podsakoff et al., 1996), leaders have positive attitudes about their followers with regard to organisational vision (O'Regan \& Ghobadian, 2007). DEPZ performance depends mostly on leader-follower relationships. Here, transformational leadership has a positive effect $(b=0.298, p<0.01)$ on organisational change. In the same vein, transactional leadership has an effect on subordinates' relationship with contingent reward practices. Therefore, transactional leadership has a positive effect $(b=0.18, p<0.05)$ on organisational change. Transactional leadership can satisfy subordinates.
In terms of the employment conditions of the DEPZ, as mentioned in Instructional Manuals I and II, enterprise workers must receive non-financial and financial benefits, although Zohir (2007) reports some doubts about those compensations as incentive packages. This study confirms that the instructional manual (compensation package) also has a positive effect on, and significant relationship with $(b=0.189, p<0.05)$, organisational change.

For increasing production volumes, and to reduce production costs, DEPZ entrepreneurs do not want unionisation in the DEPZ. Investors' pressure is another factor. Unionisation in DEPZ is the cause of lower production and leads to threats of plants or factories closing down. Therefore, trade unions have been banned in the DEPZ. Bhattacharya (1998), Hossain (2002), Zohir (2007), Siengthai and Bechter (2001), Islam and Siengthai (2009), Kleiner and Lee (1997) and the United States government have found contradictory results. The empirical results of this study have shown that unionisation has a negative relationship with organisational change $(b=-0.10, p<0.05)$.

In DEPZ enterprises, there are more females (64\%) than males. In managerial-level jobs, males dominate the field. Study results revealed that there is no mean difference between males and females in terms of organisational change. There was also no mean difference between manager and assistant manager job levels for organisational change. DEPZ enterprises are considering MBA degrees for managerial jobs rather than other degrees. The post hoc results found that MBA degrees have a significant effect on DEPZ organisational performance as well as organisational change. In addition, types of enterprises (foreign owned, locally owned and joint ventures) have mean differences and significant effects on organisational change. The radar diagram results confirmed that the variables the author measured for organisational change have closer relationships.

In conclusion, one can say that, for organisations to introduce change to cope with the ongoing changes in the global environment, the firms operating in the DEPZ need to manage their organisational learning and communication and improve their transformational and transactional leadership.

At the same time, with regard to HRM, compensation or reward is a very significant factor in organisational change.

Finally, labour welfare forum unionisation influences and leads organisational change for improving productivity.

\section{Managerial implications}

DEPZ factories do not carry out research and development activities. It should emphasise the provision of skilled personnel and of supplying quality products with competitive prices, thereby satisfying customers and investors.

To prevent unrest within DEPZ enterprises, management teams should take initiatives to provide good incentive 
packages and good working environments. Furthermore, they must ensure and monitor good HRM practices because good HRM and leadership can promote the performance of organisations through organisational change.

In this study, the author found that transformational leadership has a significant effect on organisational change. Therefore, simply providing a good working environment and good salaries for good work would not be sufficient or effective for organisational change. Leaders should be able to inspire their people in the change implementation process.

\section{Suggestions for future research}

In this study, the author drew the sample from DEPZ manufacturing enterprises at managerial level jobs. The author drew the sample from three types of enterprises (foreign owned, locally owned and joint venture enterprises).

However, this study did not conduct comparative analysis to investigate type-wise effects on organisational change. Furthermore, similar factories are operating just outside the DEPZ premises. Therefore, this study could have extended beyond DEPZ manufacturing enterprises to investigate the leadership abilities, organisational behaviours and HRM practices for organisational change.

This study has not considered enterprises outside the DEPZ. Therefore, researchers need to conduct future studies on manufacturing enterprises that are in the DEPZ as well as outside it to investigate the effects of, and relationships between, the set of variables the author used in this study. Even though there are eight economic and industrial zones operating in Bangladesh, the author did not draw the sample from all of the zones.

Therefore, future studies could extend their scope to all the export-processing zones.

\section{Research limitations}

The author conducted the study using a questionnaire survey. He drew the sample from organisations that operated inside the Dhaka export processing zone, although there are similar organisations outside the DEPZ.

The author selected the respondents from only the managerial levels of employees, although there are many others who could have provided valuable information. Therefore, considering the scope of this study, one could say that a study with a wider sample would have been more comprehensive and yielded more reliable research findings.

The findings have shown that there are significant positive relationships between some of the independent variables (like organisational learning, compensation, unionisation, transformational leadership and transactional leadership) with organisational change. On the other hand, the author did not find that some of the independent variables (like recruitment and selection, performance appraisal, organisational culture and employee motivation) correlated positively with organisational change.

The author suggests that longitudinal case studies and observations, which use ethnographic approaches, could improve our understanding of leadership, HRM and their relationships with organisational change.

\section{Conclusion}

In the process of economic development, the DEPZ plays a significant role in generating employment, accelerating export and motivating local and foreign investors. The organisational behavioural components (like employee motivation and learning) and leadership (like abilities, knowledge, skill and HRM) are playing very important and crucial roles for the growth of DEPZ enterprises.

This study aimed to identify the relationships between leadership, organisational behaviour variables, HRM and organisational change. One measures organisational behaviours by measuring organisational culture, organisational learning, employee motivation and commitment. One measures leadership by measuring transformational and transactional leadership. One measures HRM by measuring recruitment and selection, performance appraisal, compensation and unionisation.

All the independent variables had a relationship with the dependent variable (organisational change) in the expected direction.

Based the empirical data analyses, the author found that only five independent variables had significant relationships with organisational change. They are organisational learning, transformational leadership, transformational leadership behaviour, compensation or reward and unionisation.

\section{Acknowledgements Competing interests}

The author declares that he has no financial or personal relationship(s) that may have inappropriately influenced him in writing this article.

\section{References}

Abrahamson, E. (2004). Change Without Pain. Boston: Harvard Business School Press. Aggarwal, A. (2005). Performance of Export Processing Zones: A comparative analysis of India, Sri Lanaka and Bangladesh. Indian Council for Research on International Economic Relations, New Delhi.

Alas, R., Vadi, M., \& Sun, W. (2009). Impact of work-related values upon attitudes toward changes and organisational learning in Chinese organization. Chinese Management Studies, 3(2), 117-129. http://dx.doi.org/10.1108/17506140910963620

Andrew, B. (1998). Organisational culture. Prentice Hall, (2nd Eds.), England.

Arthur, J.B. (1994). Effects of Human Resource Systems on Manufacturing Performance and Turnover. Academy of Management Journal, 37(3), 670-87. http://dx.doi. org $/ 10.2307 / 256705$

Avolio, B.J., Bass, B.M., \& Jung, D.I. (1999). Re-examining the components of transformational and transactional leadership using the multifactor leadership questionnaire. Journal of operational and organisational psychology, 72(4), 441462. http://dx.doi.org/10.1348/096317999166789 
Babbie, E. (2004). The practice of social research. CA: Wadsworth/Thomson Learning.

Bach, S. \& Sisson, K. (2000). Personnel Management in perspective. In Bach, S. and Sisson, K. (Eds), Personnel Management, A Comprehensive Guide to Theory and Practice, (3rd Edn.). Blackwell, Oxford, pp. 3-42.

Bass, B.M. (1985). Leadership and Performance Beyond Expectation. Free Press, New York, NY.

Bass, B.M. (1990). Bass and Stogdill's Handbook of Leadership: Theory, Research and Managerial Applications, (3rd Edn.). Free Press, New York, NY.

Becker, B.F., \& Huseild, M.A. (1998). High performance work systems and firm performance: A synthesis of research and managerial implications. Research in Personnel and Human Resource

Bhattacharya, D. (1998). Export Processing Zones in Bangladesh: Economic impact and social issues, Multinational Enterprises Programme. Working Paper No. 80. Geneva, ILO.

Bohlander, G., \& Snell, S. (2004). Managing Human Resources. (13th ed.). USA. Thomson South-Western. PMCid:321764

Bowen, D.E., \& Ostroff, C. (2004). Understanding HRM-FIRM Performance Linkage: The Role of the 'Strength' of the System'. Academy of Management Review 29(2), 203-221. http://dx.doi.org/10.5465/AMR.2004.12736076, http://dx.doi. org/10.2307/20159029

Bower, D.G., and Seashore, S.E. (1966). Predicting organisational effectiveness with a four-factor theory of leadership. Administration Science Quarterly, 11, 238-263. http://dx.doi.org/10.2307/2391247

Brown, D.R., and Harvey, D. (2006). An experimental approach to organisation development (7th Edn.). NJ: Prentice-Hall

Burns, J. M. (1978). Leadership. Harper and Row, New York, NY.

Cao, G., Clarke, S., \& Lehaney, B. (2000). 'A system view of organisational change and

Castro, C.B, Perinan, M.M.V., \& Bueno, J.C.C. (2008). Transformational leadership and followers' attitudes: the mediating role of psychological empowerment. The International Journal of Human Resource Management, 19(10).

Chen, C.C., and Meindl, J. R. (1991).The construction of leadership images in the popular press: The case of Donald Burr and People Express. Administrative science Quarterly, 36, 512-551. http://dx.doi.org/10.2307/2393273

Chen, S.-J. (2007). Human resource strategy and unionization: evidence from Taiwan. International Journal of Human Resource Management, 18(6), 1116-1131. http:// dx.doi.org/10.1080/09585190701321948

Chew, Y. T., \& Choo, S. M. (2008). A Study of the Change Management and Challenges in a Bank. Research and Practice in Human Resource Management, 16(2), 100118.

Collins, C., \& Smith, K. (2003). Strategic Human Resource Practices, top management team social network and firm performance: the role of human resource practices in creating organisational competitive advantages. Academy of Management in creating organisational competitive advantages. Academy
Journal, 46(6), 740-51. http://dx.doi.org/10.2307/30040665

Daft, L. (2003). Management, South-western, (6th edn.). Australia.

Dansereau, F., Yammarino, F.J., \& Markham, S.E. (1995). Leadership: The Multiple-leve approaches. Leadership Quarterly, 6(2), 97-109. http://dx.doi.org/10.1016/10489843(95)90030-6

Das, A. (2006). Leadership competencies and Total Quality Management. PhD dissertation, Thailand: School of Management, Asian Institute of Technology.

Datta, D.K., Guthrie, P.J., \& Wright, P.M. (2005). Human Resource Management and Labour Productivity: Does Industry Matter? Academy of Management Journal, 48(1), 135-145. http://dx.doi.org/10.5465/AMJ.2005.15993158

Davis, S. (1984). Managing Corporate Culture. Balinger, Cambridge, MA.

Delery, J. (1998). Issues of fit in strategic human resource management: implications for research. Human Resource Management Review, 8(3), 289-309. http://dx.doi. org/10.1016/S1053-4822(98)90006-7

Denison, D.R. (1990). Corporate Culture and Organisational Effectiveness, John Willey \& Sons, New York, NY.

Dessler G. (2003). Human Resource Management. (9th Edn.), Prentice-Hall of India.

DiBella, A., Nevis, F., \& Gould, J. (1996). Understanding Organisational Learning Capability. Journal of Management Studies, 33(3), 361-379. http://dx.doi. org/10.1111/j.1467-6486.1996.tb00806.x

Dumphy, D., Turner, D., \& Crawford, M. (1997). Organisational Learning as the Creation of Corporate Compentencies. Journal of Management, 16(4), 232-249.

Edger, F., \& Geare, A. (2005). HRM practice and employee attitudes: different measures - different results. Personnel Review, 34(5), 534-549. http://dx.doi. org/10.1108/00483480510612503

Eisenbach, R., Watson, K., \& Pillai, R. (1999). Transformational leadership in the context of organisational change. Journal of Organisational Change Management, 12(2), 80-88. http://dx.doi.org/10.1108/09534819910263631

Eusuf, M.A., Faruque, A.B.M., \& Rahman, A. (2007). Institution for facilitating FDI: Issues for BEPZA. Bangladesh. IPPG Program office, IDPM, School of Environment \& Development, University of Manchester, UK.

Francis, H. (2003). HRM and the beginnings of organisational change. Journal of Organisational Change, 16(3), 309-327. http://dx.doi.org/10.1108/0953481031 0475541

Gerhardt, P.L. (2004). Transformational and Transactional Leadership in Retail. Retrieved October 01, 2009, from http://www.google.co.th/search?hl = en\&rlz = $1 \mathrm{~W} 1 \mathrm{GGLL}$ en\&q = transactional+leadership+and+organisational+change\&start = $10 \&$ sa $=\mathrm{N}$
Goffee, R., \& Jones, G. (2006). Why Should Anyone Be Led By You? Harvard Business School Press.

Government of Bangladesh (GOB), (01 August, 2010). Bangladesh Gazette, Dhaka, Bangladesh Parliament.

Government of Bangladesh (GOB), (2009). Bangladesh Economic Review, Ministry of Finance, Dhaka, Bangladesh.

Government of Bangladesh (GOB), (1989). BEPZA Instructional Manual I and II, Dhaka, Bangladesh.

Goh, S., \& Richards, G. (1997). Benchmarking the Learning Capability of Organizations. European Management Journal, 15(5), 575-83. http://dx.doi.org/10.1016/ European Management
S0263-2373(97)00036-4

Gooderham, P., Parry, E., \& Ringdal, K. (2008).The impact of bundles of strategic human resource management practices on the performance of European firms', International Journal of Human Resource Management, 19(11), 2041-56. http:// International Journal of Human Resource
dx.doi.org/10.1080/09585190802404296

Gopalakrishnan, S. (2007). In the Name of Growth: The Politics and Economics of India's Special Economic Zones. A study prepared for Council for Social Development. New Delhi: council for Social Development, India. pp.1-110. Retrieved September 18, 2010, from http://casi.ssc.upenn.edu/iit/rjenkins

Gravin, D.A. (1993). Building a Learning Organization. Harvard Business Review, 71(4), 78-91.

Hair, J.F., Black, W.C., Babin, B.J., Anderson, R.E., \& Tatham, R.L. (2006). Multivariate Data Analysis, (6th ed.). pp.102-103.

Harigopal, K. (2001). Management of organisational change, Sage Publication India Pvt. Ltd, New Delhi.

Harris, C., Cortvriend, P., \& Hyde, P. (2007). Human Resource Management and Performance in healthcare organizations. Journal of Health Organization and

Noe, R. A., Hollenbeck, J.R., Gerhart, B., \& Wright, P.M. (2006). Human Resource Management. McGraw-Hill, Irwin.

Hossain, I. (2002). Export Processing Zones in Bangladesh and Industrial Relations. In Muqtada, M., Singh, A.M., Rashid, M.A. (1st ed.). Bangladesh Economic and Socia Challenges of Globalisation, The University Press Limited, Dhaka, pp.169-191.

House, R.J. (1971). A path-goal theory of leader effectives. Administrative Science Quarterly, 16, 321-339. http://dx.doi.org/10.2307/2391905House, R.J. (1996). Path-goal theory of leadership: Lessons, legacy, and a reformulated theory. Leadership Quarterly, 17(3), 323-352. http://dx.doi.org/10.1016/S10489843(96)90024-7

House, R.J., \& Mitchell, T.R. (1974). Path-goal theory of leadership. Journal of Contemporary Business, 3(4), 81-97.

Huber, G.P. (1991). Organisational Learning: the contributing process and the literatures. Organisational Science, 2(1), 88-115. http://doi.doi.org/10.1287/ orsc.2.1.88

Huselid, M.A. (1995). The Impact of Human Resource Management Practices on Turnover, Productivity and Corporate Financial Performance. Academy of Management Journal, 38, 635-672. http://dx.doi.org/10.2307/256741

ILO. (2007). Sectoral Activities Programme. ILO database on export processing zones. Working Paper, No. 251, Geneva, April, 2007.

Islam, M.Z., \& Siengthai, S. (2009). Quality of work life and organisational performance: Empirical evidence from Dhaka Export Processing Zone, Paper presented in ILO conference on 'Regulating for Decent Work', Geneva, July 07-10, 2009.

Jean-Marie, (1996). The impact of human resource management on organisational performance: Theory and research. European Management Journal, 14(6), 62837. http://dx.doi.org/10.1016/S0263-2373(96)00059-X

Jung, D.I., Berson, Y., Avolio, B.J., \& Bass, B.M. (2003). Predicting unit performance by assessing transformational and transactional leadership, Journal of Applied Psychology, 88(2), 207-218. http://dx.doi.org/10.1037/0021-9010.88.2.207, PMid:12731705

Karatepe, O.M. \& Uludag, O. (2006). Conflict, exhaustion, and motivation: A study of frontline employees in Northern Cyprus hotels. International Journal of Hospitality Management, Early Published. (online) Elsevier.

Keller, R. (2007).Sustainable Improvement Requires A Culture Change. Continuous Improvement. April 12, 2007, from www.industrweek.com

Kets de Vries, M. (1996). Leaders who make a difference. European Management Journal, 14(5), 486-493. http://dx.doi.org/10.1016/0263-2373(96)00042-4

Kleiner, M.M., \& Lee, Y.M. (1997). Works Councils and Unionisation: Lessons from South Korea. Industrial Relations, 36, 1-16. http://dx.doi.org/10.1111/00198676.381997001

Koskosas, I.V., Charitodui, G., \& Louta, M. (2008). The role of organisational cultures in Information-Systems Security Management: A Goal-Setting Perspective. Journa of Leadership Studies, 2(1), 7-17. http://dx.doi.org/10.1002/jls.20042

Kotter, J.P. (1995). Leading change: Why transformational efforts fail. Harvard Business Review, March/April, pp. 59-67.

Kotter, J.P., \& Heskett, J.L. (1992). Corporate Culture and Performance. The Free Press, New York, NY

Kotter, P.J. (1998). What Leaders Really Do? Harvard Business Review on Leadership, Harvard Business School Press, USA. PMCid:1722610

Kotter, P.J. (2007). Leading Change: Why Transformation Efforts Fail. Harvard Business Review, 85(1), 96.

Kreitner, R. \& Kinicki, A. (2001). Organisational Behaviour, Fifth Edition, New York: McGraw-Hill. 
Lewis, P.S., Goodman, S.H., \& Fandt, P.M. (2001). Management: Challenges in the 21st Century. (3rd Edn.), South-western.

Likert, R. (1932). A Technique for the Measurement of Attitudes. New York: Archives of Psychology.

Murayama, M., \& Yokota, N. (2009). Review of Labour Economic and Political Weekly, May 30, June 5, 2009, 44(22), 73.

Martinez-Sanchez, Perez-Perez, M., Vela-Jimenez, M.J., \& de-Luis-Carnicer, P. (2008) Telework adoption, change management, and firm performance. Journal of Organisational Change Management, 21(1), 731

McShane, S.L., \& Von Gilnow, M.A. (2000). Organisational Behaviour. McGraw-Hill, New York, NY

Nawaz, A.S.M. (2005). Model of Human Resource Management: A critical Review of Their Impact on Organisational Effectiveness. The Cost and Management, 33(4) 56-62.

Noe, R. A., Hollenbeck, J.R., Gerhar, B., \& Wright, P.M. (2006). Human Resource Management: Gaining a Competitive, Advantage, (5th Edn.). New York: McGrawHill Irwin.

Nunnally, J.C. (1978). Psychometric Theory, McGraw Hill Book Company. New York.

O'Regan, N., \& Ghobadian, A. (2007). Leadership and its Impact on the Use of Process Technologies and Management Practices in the Manufacturing Sector. International Journal of Business Performance Management, 9(4), 419-433. http://dx.doi.org/10.1504/IJBPM.2007.013363

O'Reilly, C.A., \& Chatman, J.A. (1996). Culture as a social control: Corporations, culture, and commitment, In B. M. Staw and L.L. Cummings (Eds.), Research in Organisational Behaviour, 18, 157-200. Greenwich, CT: JAI Press.

O'Toole, M. (2002). The Relationship between Employees' Perceptions of Safety and Organisational Culture. Journal of Safety Research, 33, 231-243. http://dx.doi. org/10.1016/S0022-4375(02)00014-2

OECD, (2002). Organisational change and firm performance. Industry Issues.

OECD, (2001). Public Sector Leadership for the 21st Century.

Parker, R., \& Bradley, L. (2000). Organisational culture in the public sector: evidence from six organizations. International Journal of Public Sector Management, 13(2), 125-141. http://dx.doi.org/10.1108/09513550010338773

Pawar, B.S. (2003). Central conceptual issues in transformational leadership research. Leadership and Organisational Journal, 24(7), 397-402. http://dx.doi. org/10.1108/01437730310498596

Pedler, M., Burgoyne, J., \& Boydell, T. (1990). The Learning Company: A Strategy for Sustainable Development. London: McGraw-Hill. PMid:2115050, PMCid:502450

Pfeffer, J. (1994). Competitive Advantage through People. California Management Review, 36, 9-29. http://dx.doi.org/10.2307/41165742

Podsakoff, P.M., MacKenzie, S.B., \& Bommer, W.H. (1996). Transformational Leade Behaviours and Substitutes for Leadership as Determinants of Employee Satisfaction, Commitment, Trust, and Organisational Citizenship Behaviour. Journal of Management, 22(2), 259-298.

Rao, P., Y.V.S.S.S.V. (2005). Motivation model for improving productivity in a manufacturing unit - a success story. International Journal of Productivity and Performance Management, 55(5), 430-436. http://dx.doi. org/10.1108/17410400610671453

Rashid. A., Sambasiva M., \& Johari, J. (2003). The influence of corporate culture and organisational commitment on performance. Journal of Management Development, 22(8), 708-728. http://dx.doi.org/10.1108/02621710310487873

Reimann, T., \& Oedewald, P. (2002). The Assessment of Organisational Culture: A Methodological Study, VTT Research Notes, Finland. PMCid:1462267

Robbins, S.P. (2003). Organisational Behaviour. Prentice Hall (10th eds.), England.
Robertson, P.J., Roberts, D.R., \& Porras, J.I. (1993). Dynamics of planned organisational change: assessing empirical support for a theoretical model. Academy of Management Journal, 36(3), 619-634. http://dx.doi.org/10.2307/256595

Rodrik, D. (1997). Has Globalization Gone Too Far? Washington, DC: Institute for International Economics.

Schein, E. H. (1992). Organisational Culture and Leadership. (2nd Edition), Jossey Bass,

Schermerhorn, J., Hunt, J., \& Osborn, R. (2005). Organisational Behaviour. John Wiley \& Sons, Inc., Ninth Edition, USA.

Senge, P. (1990). The Fifth Discipline: The Art \& Practice of the Learning Organization, New York: Doubleday.

Siengthai, S. \& Bechter, C. (2001). Strategic Human Resource Management and Firm Innovation. Research and Practice in Human Resource Management, 19(1), 3557.

Stata R., (1989). Organisational Learning - The key to management Innovation. Sloan Management Review, Spring, pp. 63-73.

Stroh L.K., Brett, J.M., Baumann, J.P., \& Reilly, A.H. (1996). Agency Theory and Variable Pay Compensation Strategies. Academy of Management Journal, 39(3), 751-767. http://dx.doi.org/10.2307/256663

Stone J. Raymond. (2002). Human Resource Management. (4th Edition), John Wiley \& Sons. Australia, Ltd. pp. 572-868.

Thang, L. C. (2004). Managing Human Resources in Vietnam: An empirical study of an economy in transition. Doctoral Dissertation, No. SM-04-07. Thailand: School of Management, Asian Institute of Technology.

Thomas, J.B., Sussman, S. W., \& Henderson J.C. (2001). Understanding 'Strategic Learning': Linking Organisational Learning, Knowledge Management, and Sensemaking Organization Science, 12(3), 331-345. http://dx doi.org/10.1287/ orsc.12.3.331.10105

Tsang, E.W.K. (1997). Organisational Learn and The Learning Organization: A Dichotomy between Descriptive and Prescriptive Research. Hunan Relations, 50(1), 73-89. http://dx.doi.org/10.1177/001872679705000104

Ulrich, D. (1997). Human Resource Champion, The next Agenda for Adding value and Delivering results, Harvard Business School Press, Boston.

Vera, D., \& Crossan, M. (2004). Strategic Leadership and Organisational Learning. Academy of Management Review, 29(2), 222-240. http://dx.doi.org/10.5465/ AMR.2004.12736080, http://dx.doi.org/10.2307/20159030

Wilson, A.M. (2001). Understanding organisational culture and the implication for corporate marketing. European Journal of Marketing, 35(3/4). http://dx.doi. org/10.1108/03090560110382066

World Bank. (1996). Bangladesh Government that works: Reforming the Public Sector University Press Ltd, Dhaka. July, 1996. Report No. 15182 BD.

Wright, P.M., McMahan, G. C., \& McWilliams, A. (1994). Human Resources and Sustained Competitive Advantage: A Resource based Perspective. Internationa Journal of Human Resource Management, 5(2), 301-326. http://dx.doi. org/10.1080/09585199400000020

Youndt, M., Snell, S., Dean, J., \& Lepak, D. (1996). Human Resource Management manufacturing strategy and firm performance. Academy of Management Journal, 39(4), 836-66. http://dx.doi.org/10.2307/256714

Zheng C., Morrison, M., \& O'Neill, G. (2006). Anempirical study of high performance HRM practice in Chinese SMEs. International Journal of Human Resource Management, 17(10), 1772-1803. http://dx.doi.org/10.1080/09585190600965282

Zohir, C.S. (2001). Gender Balance in the EPZ: A Socio-Economic Study of Dhaka Export processing zone in Bangladesh, Research Report, Bangladesh Institute of Development Studies, Dhaka. PMCid:3333237

Zohir, C.S. (2007). Role of Dhaka Export Processing Zone: Employment and Empowerment, Research Report, No. 181, Bangladesh Institute of Development Studies, Dhaka. 